\title{
PWDs Accessibility Audit: Commercial complexes, Klang Valley, Malaysia
}

\author{
Ahmad Ezanee Hashim, Siti Aida Samikon, \\ Faridah Ismail, Hikmah Kamarudin, \\ Faculty of Architecture, Planning and Surveying, \\ Universiti Teknologi MARA, 40450 Shah Alam, Selangor, Malaysia \\ ezanee54@gmail.com
}

\begin{abstract}
Barriers may restrict the mobility of people with disabilities (PWDs) in a building. This research identifies the effectiveness of accessibility in commercial complexes in the Klang valley in the state of Selangor Malaysia. Data were based from semi structured interviews and site audit with four groups of respondents of different type of disability. The finding reveals it is mandatory requirements to provide user friendly accessibility within and outside buildings as there are weaknesses found such as poor thought out solution, poor quality materials, limited guidelines and weak enforcement by the relevant authorities. The findings highlighted could be a benchmark for PWDs building industry in developing a user friendly and accessible building environment in commercial complexes.
\end{abstract}

Keywords: access, effectiveness, people with disabilities (PWDs)

eISSN 2514-751X @ 2018 . The Authors. Published for AMER ABRA CE-Bs by e-International Publishing House, Ltd., UK. This is an open-access article under the CC BY-NC-ND license (http://creativecommons.org/licenses/by$n c-n d / 4.0 /$ ). Peer-review under responsibility of AMER (Association of Malaysian Environment-Behaviour Researchers), ABRA (Association of Behavioural Researchers on Asians) and CE-Bs (Centre for EnvironmentBehaviour Studies), Faculty of Architecture, Planning \& Surveying, Universiti Teknologi MARA, Malaysia.

https://doi.org/10.21834/aje-bs.v3i8.291 


\subsection{Introduction}

United Nations (2012) statistic reported that disabled people account 10 percent of the global population and approximately 7 percent of the world's PWDs are in developing countries. Malaysia as one of the developing countries with 28 million populations enlighten awareness among the Malaysian built environment. Disability can be defined as lack of ability to perform a range of normal activity. It may involve physical or cognitive limitation such as chronic diseases, and inability to speak or walk. For wheelchair's user may feel inconvenienced due to physical impediment in narrow toilet and un availability of ramp in a building.

Previous studies revealed that Malaysian development policies and regulations are lacking in the provision of user friendly built environment which include barrier-free and disabled-friendly environment although these are stated in the building code and legislation (Tan, 2008). In the Malaysian Standard 1331:Code of Practice for Access for Disabled People Outside Buildings there is no enforcement to provide for accessibility outside buildings for disabled persons. Similarly in MS 1183:1990, Code of practice on Access for Disabled Person To Public Buildings. The Building Code Regulation for Disable People, MS 1184 (2002) only explained the basic requirements of building element and facilities to disable people. This study will help to recognize some of the problems on accessible issues in commercial complex in Malaysia. Through the findings, several recommendations are highlighted that could become a PWDs benchmark for a better conducive built environment.

\subsection{Disabled People}

Who are the disabled people? Many of us did not realise that we are physically disabled at some point in our lives. A child, a person with a broken leg, a parent with a pram, an elderly person, etc. are all disabled in one way or another. Those who remain healthy and ablebodied all their lives are few (Wikipedia 2010). Disabled people are whom that may be poor in physical, cognitive, mental, sensory, emotional and developmental or some combination of these (World Health Organization, 2011).

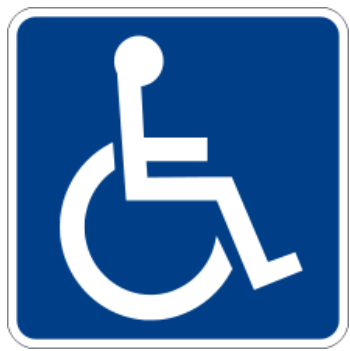

Figure 1: International Symbol of Access (2011)

There are approximately 2.7 million disabled people exclude the number of senior citizens who become disabled through old age and illness (Yaakub, 2006). A total number of 197,519 people have been registered with the Department of Social Welfare Malaysia (DSW) in the 
year 2006. Lacking in an accessible environment within and without buildings will restrict these people enjoy their life (Tan, 2008). Some of the basic facilities that should be considered by the building industry in the built environment included disable toilet, barrier free and accessible access, handrails in lift car, car parking facilities, accessible public phone, clear exit and entrance signage. Generally some of these facilities are provided and have been appraised by the Deputy Prime Minister, (2008).

\subsection{Code of Practice on Access for Disabled People: Design and Architectural Elements}

Malaysian Standards are developed through consensus by committees which comprised of balanced representatives from of producers, users, consumers and related stake holders. Malaysian Standards and code of practice are aligned to or adoption of international standards. In this standard, regulation for disabled people refers to MS 1184 (2002) that focus on comfort of the facilities provided. The current guideline for local buildings and facilities to permit access to disabled people has been specified in the Malaysian Standard 1184: 2002 - Code of Practice on Access for Disabled Persons to Public Buildings. However, due to the weak enforcement and lack of implementation acts the service providers and developers have neglected by making excuses on the extra costs that can be saved (Asiah 2005)

The requirements for barrier free area design are inclusive of open spaces, recreational areas and pedestrian routes. It introduces solutions to the principal problems in the design of an accessible outdoor environment. According to Uum Al-Qura University (2007) five major elements have to be considered under the designing phase of commercial complex for disabled are:

1. Obstructions - Design a barrier-free path for the safety and independence of disabled people, especially the sightless.

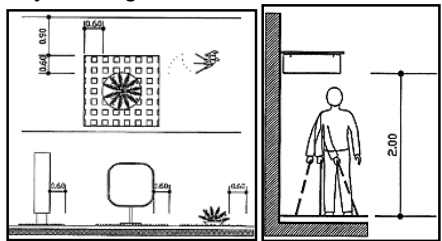

Figure 3.1: Obstruction.

2. Street furniture -Without obstructing, the free passage of pedestrians along travel routes and the accessible amenities are design for people's convenient.
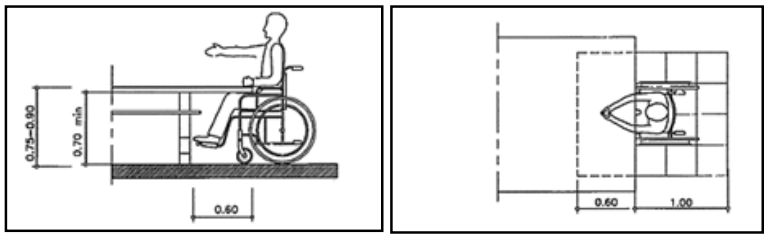

Figure 3.2: Dimension of table in order to fit wheelchair. 
3. Curb ramps - Overcome changes in level between the pavement and the road surface and on the pavement.

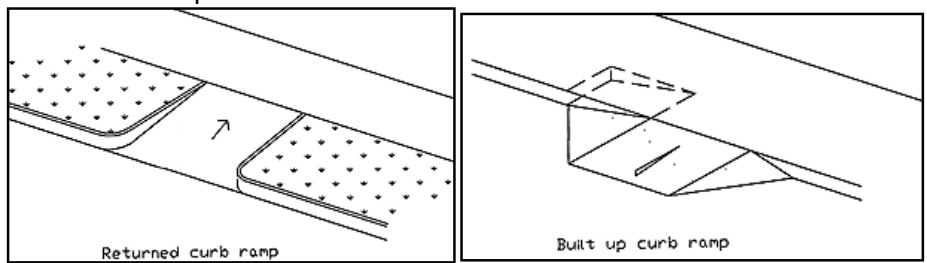

Figure 3.3: Curb ramps design to avoid confusion of sightless pedestrians.

4. Pathways - Provide clear, obstruction-free, level and wide pathways for the convenience of the sightless and people with mobility problems.
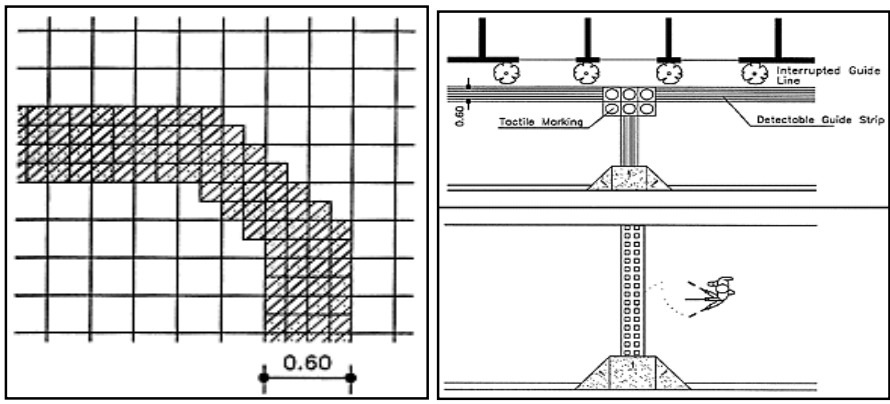

Figure 3.4: Use of textured pavements for easy to detection by a sightless person using a long white cane/stick.

5. Parking - Provide accessible parking facilities as close to the point of destination.

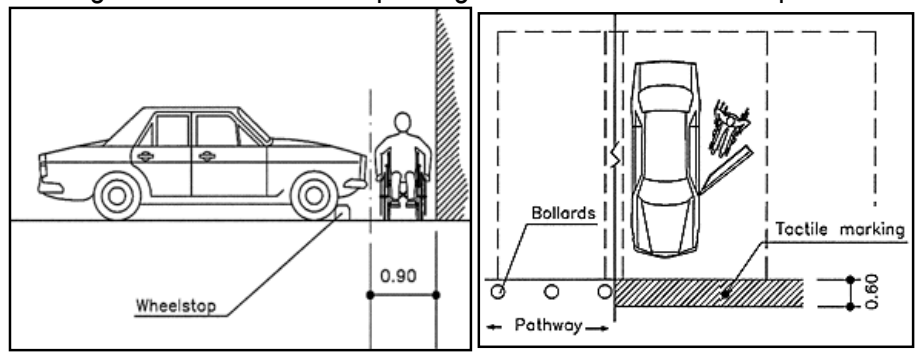

Figure 3.5: Dedicated parking design for the disabled

\subsection{Methodology And Research Scope}

In the context of facilities provision for the disabled person, the target respondent samples are:

1. Wheelchair users; 
2. People with limited walking abilities (with crutches);

3. People with vision impaired

4. People with hearing impaired

As discussed in the literature review, five major elements of barrier-free access were audited. Four commercial shopping complexes located in Selangor were selected as case studies i.e. mall located in Puchong, shopping centre in Ampang, South City Plaza in Seri Kembangan and Shah Alam Commercial Complex. All four commercial complexes were built between the year of 1990 s to 2000 and generally are in serviceable condition As to examine the respondents' feedback on the facilities and accessibility within the selected shopping complexes, the data were collected from the abovementioned group of respondents. The total number of respondents is 26 , comprised of six respondents for each category.

\subsection{Findings and Critical Review of Case Study: Commercial Complexes}

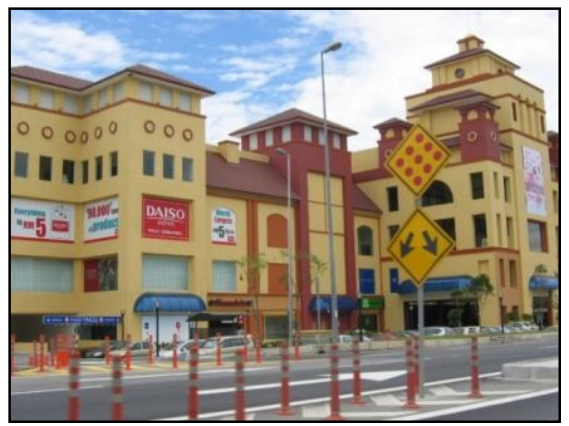

Figure 1: IOI Mall, Puchong, Selangor, Malaysia

The first case study, the IOI Mall in Puchong is a modern 3-storey shopping mall with total areas of 650,000 square feet (Figure 1). The complex was launched in June 1996 with Mediterranean concept of architecture designed. From the survey and on-site audit site, it was found that wheelchair users with limited walking abilities considered the complex as a barrier-free environment. However, the IOI Mall should improve the signage level in the selected areas for easier identification of facilities with safe and clear walking path for people with vision impaired. For respondents with hearing impaired disabilities, they highlighted the important of a clear signage to move without getting assistance. The level of assessment for each group of respondents on the facilities and accessibility available in this complex are as follows. 
Table 1: Assessment level according to facilities provided for PWDs, Commercial Complex Puchong. Selangor

\begin{tabular}{|l|c|}
\hline \multicolumn{1}{|c|}{ GROUP } & ASSESSMENT LEVEL (1-5) \\
\hline Wheelchair user & 4 \\
\hline Vision impaired & 4 \\
\hline Hearing impaired & 5 \\
\hline People with crutches & 5 \\
\hline
\end{tabular}

Table 1.1: Perception of PWDs on provided facilities in IOI Mall, Puchong, Selangor, Malaysia

\begin{tabular}{|l|l|l|}
\hline Item & Group & Perception \\
\hline 1. & $\begin{array}{l}\text { Wheelchair user } \\
\text { and people with } \\
\text { limited walking } \\
\text { abilities }\end{array}$ & $\begin{array}{l}\text { Both respondents of wheelchair and crutch categories found that it is easier for } \\
\text { them to move around in IOI Mall. However, comprehensive improvements for } \\
\text { some areas are needed to ensure equal opportunities for everyone. }\end{array}$ \\
\hline 2. & $\begin{array}{l}\text { Sightless and Vision } \\
\text { impaired }\end{array}$ & $\begin{array}{l}\text { Warning indicator is needed to warn person with vision impaired. } \\
\text { The indicators help in : } \\
\text { Direction - to indicate a clear continuous accessible path of travel, change of floor } \\
\text { levels } \\
\text { Location - to provide assistance to locate facilities such as pedestrian crossing, } \\
\text { entrance to a public building, ticketing machine and phone booth }\end{array}$ \\
\hline 3. & Hearing impaired & $\begin{array}{l}\text { The hearing-impaired people generally do not face many problems accessing most } \\
\text { of the facilities at the IOI Mall. The only shortcoming addressed by them is they } \\
\text { need proper signage that would enable them to move around without the help of } \\
\text { others. }\end{array}$ \\
\hline
\end{tabular}

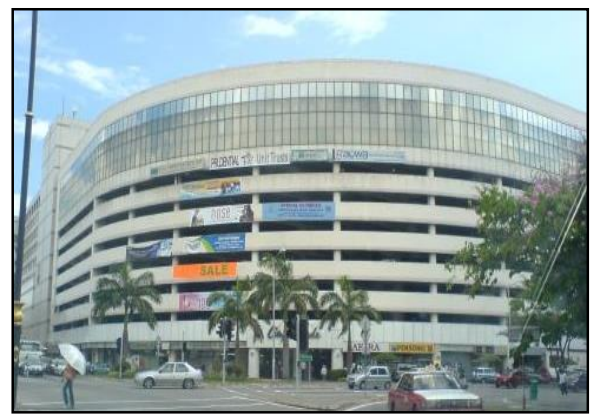

Figure 2: Commercial complex: Ampang Selangor Malaysia

The second complex is located in Ampang, Selangor (Figure 2). This complex is a four storey commercial complex. From the semi structured interviews conducted, it was found that the wheelchair user and people with limited ability faced with challenges especially in term of mobility opportunities within the complex as facilities provided to ease their movement are limited. This is proved by the least score of assessment as shown in Table 2. Others results shows that the vision impaired respondents recorded the second lowest assessment level. Based on the findings shown in Table 2.1, they claimed that the locations of furniture 
are not suitable and not easily accessible. They emphasised that devices such as flashing lighting and signal for vision impaired group must be provided.

Table 2: Assessment level according to facilities provided for PWDs in Ampang, Selangor.

\begin{tabular}{|l|c|}
\hline GROUP & ASSESSMENT LEVEL (1-5) \\
\hline Wheelchair user & 2 \\
\hline Vision impaired & 3 \\
\hline Hearing impaired & 5 \\
\hline People with crutches & 4 \\
\hline
\end{tabular}

Table 2.1: Perception of PWDs on provided facilities in Commercial Complex, Ampang, Selangor.

\begin{tabular}{|c|c|c|}
\hline Item & Group & Perception \\
\hline 1. & $\begin{array}{l}\text { Wheelchair user } \\
\text { and people with } \\
\text { limited walking } \\
\text { abilities }\end{array}$ & $\begin{array}{l}\text { The mall area is considered as a barrier-free environment. Comprehensive } \\
\text { improvement of the area is needed to ensure equal opportunities for everyone. }\end{array}$ \\
\hline 2. & $\begin{array}{l}\text { Sightless and Vision } \\
\text { impaired }\end{array}$ & $\begin{array}{l}\text { The street furniture facilities are not user friendly to the vision impaired people as } \\
\text { there are no indicators to locate those facilities. Moreover, most of the furniture } \\
\text { are not suitably located and are inaccessible for the PWDs. } \\
\text { Male and female toilets are located next to each other and could not easily } \\
\text { identified. The layout of corridors is confusing. There are obstructions in } \\
\text { circulation routes such as columns and fire extinguishers.. }\end{array}$ \\
\hline 3. & Hearing impaired & $\begin{array}{l}\text { The mall is equipped with smoke alarms and other assistive devices to warn the } \\
\text { people with hearing impaired, in case of fire. According to United state Fire } \\
\text { Administration (2012) clarifies flashing lights are only useful if they are installed } \\
\text { where a hearing-impaired person can see them. }\end{array}$ \\
\hline
\end{tabular}

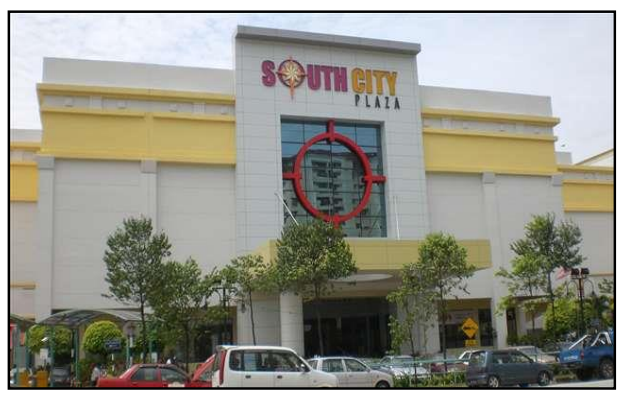

Figure 3: South City Plaza, Seri Kembangan, Selangor Malaysia

The third case study is the South City Plaza located in Sri Kembangan, Selangor. The built up area of this complex is 850,000 square feet. Findings shows that both group of wheelchair users and people with crutches have difficulties in gaining access to facilities such as the toilets due to inadequate size of toilet area and high level of floor drop. For the sightless, they claimed that the signage should be clear with visible lighting level. 
Table 3: Assessment level according to facilities provided for PWDs,Commercial Complex Seri Kembangan, Selangor, Malaysia.

\begin{tabular}{|l|c|}
\hline GROUP & ASSESSMENT LEVEL (1-5) \\
\hline Wheelchair user & 3 \\
\hline Vision impaired & 3 \\
\hline Hearing impaired & 5 \\
\hline People with crutches & 5 \\
\hline
\end{tabular}

Table 3.1: Perception of PWDs on facilities provide in Commercial Complex Seri Kembangan, Selangor, Malaysia.

\begin{tabular}{|l|l|l|}
\hline Item & Group & Perception \\
\hline 1. & $\begin{array}{l}\text { Wheelchair user } \\
\text { and people with } \\
\text { limited walking } \\
\text { abilities }\end{array}$ & $\begin{array}{l}\text { Both wheelchair and crutch users group of respondents found that it were very } \\
\text { challenged for them to use certain facilities in this complex. The disabled toilet } \\
\text { is inaccessible to the wheelchair users due to the high level of floor drop and the } \\
\text { absence of ramp. For the toilet cubicle, although labeled as disabled toilet yet } \\
\text { the floor area is inadequate for them to move and use the facilities. }\end{array}$ \\
\hline 2. & $\begin{array}{l}\text { Sightless and Vision } \\
\text { impaired }\end{array}$ & $\begin{array}{l}\text { Adequate and proper signage is required to give information, direction, } \\
\text { identification and safety to people with vision impaired. Signs must be simple, } \\
\text { short and easily understood and need to be suitably lit by good lighting or by } \\
\text { use of back illumination and free of reflection. Braille should be used, if possible, } \\
\text { wherever embossed characters are used. }\end{array}$ \\
\hline 3. & Hearing impaired & $\begin{array}{l}\text { Architecturally, deaf people need building designs that include open spaces, } \\
\text { rounded and sloped corners so that we can see approaching people rather than } \\
\text { hear them. We need windows and mirrors throughout the interior of the building, } \\
\text { since we cannot communicate by calling out to someone else in another room } \\
\text { we need to be able to see the other person. We also need flooring with enough } \\
\text { "give" to enable foot-stamping that will attract our own or another Deaf person's } \\
\text { attention (Singapore Association of Visually Handicapped, 1999). }\end{array}$ \\
\hline
\end{tabular}

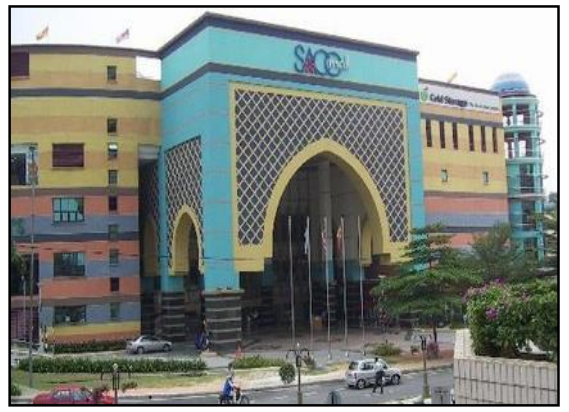

Figure 4: Shah Alam Commercial Complex, Selangor Malaysia

The fourth case study is a six-storey height commercial complex with a gross floor area of 500,000 square feet. As shown in Table 4, the wheelchair users found that accessibility within this complex is not barrier free design. While, others group of respondents found that this complex is a user friendly complex (assessment level range 4 to 5). As shown in Table 4.1, respondents with vision impaired claimed that the building provided a well lit and 
consistent optimum lighting. Meanwhile respondents with hearing impaired are comfortable with two-way lights switch at room entrance, clear visual toilet signage or indicators and visual communication devices inside all lift or elevators.

Table 4: Assessment level according to facilities provided for PWDs, Commercial Complex Shah Alam, Selangor

\begin{tabular}{|l|c|}
\hline GROUP & ASSESSMENT LEVEL (1-5) \\
\hline Wheelchair user & 3 \\
\hline Vision impaired & 4 \\
\hline Hearing impaired & 4 \\
\hline People with crutches & 5 \\
\hline
\end{tabular}

Table 4.1: Perception of PWDs on facilities provided in Commercial Complex Shah Alam, Selangor, Malaysia

\begin{tabular}{|l|l|l|}
\hline Item & \multicolumn{1}{|c|}{ Group } & \multicolumn{1}{c|}{ Perception } \\
\hline 1. & $\begin{array}{l}\text { Wheelchair user } \\
\text { and people with } \\
\text { crutches }\end{array}$ & $\begin{array}{l}\text { At the time of audit, respondents highlighted that their movement in the complex } \\
\text { are hassle free. For this reason, this complex can be considered as a barrier- } \\
\text { free environment. }\end{array}$ \\
\hline 2. & Vision impaired & $\begin{array}{l}\text { Consistent and optimum lighting is consistent and need to be glare free. } \\
\text { Fluorescent lamps and incandescent lamps also affect the colors are } \\
\text { differentiated. Interior design and decorative finish add warmth and character to } \\
\text { a building. Highlight features and shapes aiding blind and partially sighted } \\
\text { people to orientate, navigate and help them to develop mind maps. An example } \\
\text { may be highlighting a column so that it does not blend into the background or is } \\
\text { not decorated with mirrors. Reflective finishes such as marbled or tiled floors can } \\
\text { produce glare and disorient users. Complex patterns may also have the same } \\
\text { effect (Singapore Association of Visually Handicapped, 1999). }\end{array}$ \\
\hline 3. & Hearing impaired & $\begin{array}{l}\text { Other examples of universal design features that are truly universal for deaf } \\
\text { people are; easily-reachable buttons to turn on lights, shake-awake alarms, two- } \\
\text { way light switches in room entrances or bathrooms, flashing doorknockers and } \\
\text { phone-ringers, clear visual signage and indicators, visual communication } \\
\text { devices inside elevators and other enclosed spaces (Singapore Association of } \\
\text { Visually Handicapped,1999). }\end{array}$ \\
\hline
\end{tabular}

\subsection{Conclusion and Recommendation}

It can be appreciated that the commercial complex owners have increasingly taken social corporate responsibility by providing facilities for the PWDs. The findings show that general access and accessibility to the selected commercial complexes are at satisfaction level. However, there are still areas of improvement for a better quality of live in line with the concept of a caring society that Malaysian are nurturing. Poor inaccessibility found due to poor thought out the solution at the planning stage and lack of enforcement on policies and 
guidelines. The physical barriers identified throughout the study could be minimized if not totally omitted. Disable user friendly facilities should comply with the Malaysian codes of practices. The PWDs should be able to move around and use the facilities without help. The overall design of shopping mall should be accessible by PWDs as they are also customers of the mall.

This study provides a benchmark for consultants, local authorities and those concerned in the built environment profession in planning and designing PWDs user friendly commercial buildings. Consideration must be given to facilitate meaningful participation and equal opportunities for disabled persons in contributing towards the nation building process and the development of the economy. It is hoped that the National Welfare Policy and the Malaysia Vision of establishing a "Caring and Sharing Society" through the coordinated efforts involving government agencies, voluntary organizations and society at large would allow the disable community to enjoy the same right and privileges as any normal citizen of the country. Implementation of the Malaysian Standards in providing access for the PWDs and closed enforcement by the local authority is deemed crucial.

\section{Acknowledgements}

The Authors would like to acknowledge and extend heartfelt gratitude to the Government of Malaysia, Research Management Institute (RMI) and University Technology MARA.

\section{References}

Asiah Abdul Rahim (2005) 'Inclusive Design / Universal Design for Built Environment', Architect Meeting (28 September 2005), Pulau Pinang.

Disability, 2010, Wikipedia. [online] Available at <http://en.wikipedia.org/wiki/Disability> [Accessed 28 December 2011]

International Day of persons With Disabilities, 2011. [online] Available at $<$ <ttp://www.petertan.com/blog/tag/disabled-people-malaysia/>[Accessed 28 December 2011]

MS 1184:2002 'Code of Practice for Access for Disabled Persons to Public Buildings'.

Office of the Deputy Prime Minister, Access to and use of buildings, 2008

Peter Tan (8 April 2008), Peer Counsellor of Kuala Lumpur Independent Living Centre.

Unite Nations Enable, "Accessibility for the Disabled - A Design Manual for a Barrier Free Environment", http://www.un.org/esa/socdev/enable/designm/index.html retrieved on 10th January 2012

Usman Haji Yaakub (2006) 'The Malaysian Census 2000: Characteristics and Critical Issues', JMBRAS.

Venter,C. et.al., "Enhanced Accessibility for People with Disabilities Living in Urban Areas", http://www.globalridesf.org/images/DFID.pdf retrieved on 10th January 2012. 